\title{
THE ANALYSIS OF INFORMATION LITERACY SKILL THROUGH APLLICATION THE BIG 6 MODELS ON COLLEGE STUDENTS OF PGSD UNS KEBUMEN YEAR 2017
}

\section{Eko Andri Susilo, Istinganatuzzakiyah, Lhinatul Arivvia Rachma, Ratna Hidayah}

Universitas Sebelas Maret

ekoandrisusilo11@gmail.com

\section{Article History}

accepted 30/09/2018

approved $12 / 10 / 2018$

published 30/10/2018

\section{Keywords}

Information literacy, the big 6 models

\begin{abstract}
This research analyzes the information literacy skills of undergraduate students class PGSD UNS Kebumen in daily lectures activities. Information literacy is ability to find, evaluate and use the information effectively. This research was conducted in September 2018. This research use a quantitative approach, which using questionnaire for data collection. The questionnaire was made based on The Big 6 Information Literacy Models. The conclusion of this research is that students calss of PGSD UNS Kebumen already doing six steps of The Big 6 : they dicuss with other in doing works, they prefer use search engine in finding information rather than searching in library, they doing simple searching strategies in finding information and they understand in using citation.
\end{abstract}

Social, Humanities, and Education Studies (SHEs): Conference Series https://jurnal.uns.ac.id/shes

p-ISSN 2620-9284 e-ISSN 2620-9292 


\section{PENDAHULUAN}

Keberaksaraan informasi didefinisikan sebagai kemampuan untuk mengenal kebutuhan informasi guna memecahkan masalah, mengembangkan gagasan, mengajukan pertanyaan penting, menggunakan berbagai strategi pengumpulan informasi dan menetapkan informasi yang cocok, relevan dan otentik (Badan Standarisasi Nasional, 2009: 2). Kemampuan literasi informasi merupakan kemampuan mengetahui kebutuhan suatu informasi, kemampuan untuk menemukan informasi melalui berbagai cara dan kemampuan menilai informasi yang terpercaya dan akurat. The Society of College,National and University Libraries (SCONUL)menyatakan bahwa manusia yang memiliki literatinformasi akan mendemonstrasikan sebuahkesadaran bagaimana mereka mengumpulkan,menggunakan, mengatur, mensistesis, danmenciptakan informasiinformasi dan data secaraetis dan memiliki keahlian informasi untukmelakukannya dengan efektif (SCONUL, 2011). Setiap orang diharapkan mempunyai kemampuan untuk dapat menemukan informasi secara tepat guna. Dimulai dari kemampuan mengenali apa kebutuhan informasi, mencari dimana informasi itu, mengevaluasi isi informasi yang benar-benar dibutuhkan, dan menggunakan serta mengomunikasikannya secara efektif.

Menjadi seorang pembelajar di tingkat perguruan tinggi dituntut untuk memiliki kemandirian dalam belajar. Mahasiswa diharapkan tidak hanya mengandalkan informasi yang diterima dari dosen saat perkuliahan saja, tetapi secara mandiri mencari informasi yang dibutuhkan untuk dirinya. Akan tetapi faktanya terdapat cukup banyak kendala yang dialami dalam kegiatan pencarian informasi, diantaranya: 1) mahasiswa kesulitan dalam menganalisa tugas dan kebutuhan informasi yang diperlukan; 2) mahasiswa tidak mengetahui cara untuk menemukan informasi yang tepat yang dibutuhkan; 3) mahasiswa dihadapkan pada informasi yang berlimpah akan tetapi sulit menentukan yang tepat; 4) mahasiswa biasanya berfokus pada satu media informasi; 5) mahasiswa kurang menyadari etika dalam menggunakan sumber-sumber informasi. Beberapa hal terseut berkaitan dengan bagaimana informasi itu dapat diakses atau tidak. Oleh karena itu, literasi informasi menjadi sangat penting dan menjadi sebuah kebutuhan yakni hubungannya dengan kemampuan mengenali kebutuhan informasi, mencari sumber-sumber informasi, menelaah, menyaring, sampai dengan mengevaluasi konten informasi.

Pendit (2008: 119) megemukakan bahwa information literacy berkaitan dengan kemampuan mengakses dan memanfaatkan secara besar informasi yang tersedia di internet. Berkaitan dengan pernyataan tersebut, tidak mutlak semua informasi pasti berada dan ditemukan hanya di internet. Banyak sumber lain yang memberikan informasi penting, seperti perpustakaan, lembaga arsip, direktori, bibliografi, surat kabar atauapun majalah lainnya. Tetapi diantara semua itu, yang benar-benar mewakili hampir keseluruhan informasi adalah internet. Sejalan dengan itu, di era globalisasi seperti sekarang ini bidang pendidikan pun mendapatkan dampaknya. Hampir di semua lembaga pendidikan di Indonesia menciptakan dan mendirikan perpustakaan dengan fasilitas yang lengkap baik dalam hal gedung maupun perpustakaan dalam arti digital, serta pusat-pusat informasi publik yang berbasis teknologi informasi dan komputer. Hal tersebut dilakukan pemerintah dengan tujuan utama yaitu agar masyarakatnya menjadi melek informasi sebagai tahapan dari program reading literacy.

Nurohman (2014) menjelaskan fungsi perpustakaan adalah sebagai pusat informasi baik penyimpanan, penyebaran dan pemanfaatan. Penyebaran membuat perpustakaan harus mengajarkan kepada pemustaka untuk menggunakan informasi sesuai dengan kebutuhan. Untuk itu pemustaka dapat dilatih agar lebih mandiri dalam memenuhi kebutuhan informasi mereka. Kemandirian bagi seorang pembelajar tentu saja tidak sekedar terjadi di dalam ruang kelas. Mahasiswa dituntut dapat 
menyelesaikan masalah-masalah lain yang dihadapi di luar kelas, termasuk keingintahuan akan suatu topik atau pengetahuan yang tidak dibahas di ruang kelas. Informasi sangat dibutuhkan dalam menyelesaikan masalah-masalah tersebut. Melalui buku-buku, surat kabar dan majalah di perpustakaan, jurnal dan data elektronik yang dapat diakses melalui internet kampus dapat memberikan data untuk menjawab masalah terkait.

Literasi memiliki langkah-langkah yang harus dilalui. Untuk memudahkan dan meruntutkan hal tersebut diciptakanlah model literasi. Setiap model yang diterapakan dalam sebuah perpustakaan, disesuaikan dengan jenis perpustakaan dan perkembangan literasi teknologi.. Dalam peneletian ini model literasi yang diteliti yakni The Big 6. The Big 6 merupakan model literasi informasi yang dikembangkan oleh Eisenberg dan Bob Berkowitz.yang berasal dari Negara Amerika Serikat. Sulistyo (2006) menjelaskan bahwa The Big 6 sangat condong diterapkan dalam dunia pendidikan dan juga model ini adalah yang paling dikenal dan banyak digunakan untuk mengajarkan orang lain. The Bigs 6 mempunyai keunggulan yakni setiap tahap dari kebutuhan dalam menjawab suatu kasus dijelaskan dengan tahap-tahap yang mudah.

Sesuai dengan namanya, Yudistira (2017) mengemukakan bahwa The Big 6 memiliki 6 tahap penyelesaian studi kasus, yaitu:

1) mendefinisikan tugas (task definition) artinya kegiatan merumuskan dan menetapkan topik sebelum memulai penelitian/pembuatan makalah/tugas, terdapat 2 indikator antara lain yaitu mendefinisikan masalah informasi yang dihadapi dan mengidentifikasi informasi yang diperlukan.

2) strategi pencarian informasi (information searching strategies) artinya kemampuan dalam menentukan sumber-sumber informasi dan mengevaluasinya. Indikator dalam tahap ini adalah menentukan semua sumber informasi yang memungkinkan dan memilih sumber terbaik.

3) lokasi dan akses (location and acces) artinya mencoba menggali sumber yang tersedia. Indikator dalam tahap ini adalah mampu menentukan lokasi sumber secara intelektual mauun fisik dan menemukan informasi dalam sumber.

4) penggunaan informasi (use of information) artinya tahap ini membutuhkan kesediaan dalam melihat, membaca dan mendengar untuk menemukan faktafakta yang dibutuhkan dalam menjawab permasalahan. Indikator dalam tahap ini adalah mengahadapi informasi yang dipilih dan mengambil informasi yang relevan dari informasi-informasi yang digunakan.

5) sintesis (synthesis artinya tahap ini menyatukan informasi-informasi yang didapatkan sehingga dapat menjawab permasalahan yang dicari. Indikator dalam tahap ini adalah mengorganisasikan dari banyak sumber dan menyajikan informasi.

6) evaluasi (evaluation) artinya tahap ini mengevaluasi apakah tugas terselesaikan dan apakah masalah terselesaikan. Indikator dalam tahap ini adalah nilai produk dari segi efektivitas dan nilai proses.

Penelitian yang pernah dilakukan oleh Paramida dan Rachman (2013) yang berjudul Kemampuan Literasi Informasi Mahasiswa Fakultas IImu Pengetahuan Budaya Universitas Indonesia angkatan 2012 menyimpulkan bahwa mahasiswa FIB UI angkatan 2012 adalah: (1) melakukan interaksi dengan dosen dan teman untuk mendapatkan saran/masukan. Peran serta pustakawan masih tidak terlihat; (2) dalam melakukan pencarian informasi mereka lebih sering menggunakan search engine; (3) strategi pencarian yang dilakukan masih menggunakan istilah yang berkaitan dengan kata kunci yang dicari; (4) sudah memperhatikan penggunaan kutipan yang sesuai dengan kaidah ilmiah; (5) dalam mengevaluasi hasil tugas/makalah/presentasi lebih memilih mengevaluasi sendiri tanpa meminta bantuan orang lain.

Merujuk pada penelitian terdahulu yang telah berhasil menemukan model literasi yang cocok digunakan untuk menganalis kemapuan literasi informasi pada 
mahasiswa FIB UI angkatan 2012, mendorong ketertarikan peneliti untuk menyelidiki kemampuan literasi informasi melalui penggunaan model literasi The Big 6 pada mahasiswa PGSD UNS Kebumen angkatan 2017. Tujuan dilakukannya penelitian ini adalah untuk mendeskripsikan bagaimana kemampuan literasi informasi melalui penggunaan model literasi The Big 6 pada mahasiswa PGSD UNS Kebumen angkatan 2017.

\section{METODE}

Teknik pengumpulan data merupakan cara yang digunakan peneliti untuk mendapatkan data dalam suatu penelitian. Pada penelitian ini peneliti memilih jenis penelitian kuantitatif dengan metode survey.

Alat pengumpulan data yang digunakan dalam penelitian ini adalah kuesioner. Subjek penelitian ini adalah mahasiswa PGSD UNS Kampus Kebumen angkatan 2017 yang berjumlah 78 mahasiswa. Dari populasi tersebut, peneliti mengambil sampel sebanyak 36 mahasiswa. Penentuan sampel dilakukan menggunakan teknik simple random sampling. Instrumen penelitian mengacu pada indikator dari model big six. Pertanyaan sebanyak 11 butir yang terbagi menjadi 3 butir kemampuan dalam mendefinisikan tugas, 2 butir kemampuan strategi pencarian informasi, 2 butir kemampuan akses dan lokasi, 2 butir kemampuan menggunakan informasi, 1 butir kemampuan sintesis, dan 1 butir kemampuan evaluasi.

Berikut pengelompokkan menurut tesis Nurtiar (2012):

1. Sangat kurang: mahasiswa memiliki kebutuhan informasi tapi tidak memiliki pengetahuan berkaitan dengan pencarian informasi. Sehingga membutuhkan pelatihan literasi informasi. Indikator tidak pernah dilakukan.

2. Kurang: mahasiswa menyadari perlunya mendapatkan informasi dan memiliki pengetahuan berkaitan dengan pencarian informasi, tetapi sedikit. Sehingga membutuhkan pelatihan literasi informasi. Indikator jarang dilakukan 50\% - 100\%.

3. Baik: mahasiswa memiliki pengetahuan berkaitan dengan pencarian informasi dan sudah terampil tetapi masih membutuhkan pelatihan informasi. Indikator sering dilakukan $50 \%-100 \%$

4. Sangat baik: mahasiswa memiliki kepercayaan diri dalam menggunakan pengetahuan berkaitan dengan pencarian informasi dan sangat terampil menggunakan. Indikator sering sekali dilakukan 50\% - 100\%

\section{HASIL DAN PEMBAHASAN}

Peneliti menggunakan model the big 6 untuk mengetahui kemampuan literasi mahasiswa PGSD UNS Kebumen Angkatan 2017, sesuai dengan Sulistyo (2006) yang menjelaskan bahwa The Big 6 sangat condong diterapkan dalam dunia pendidikan dan juga model ini adalah yang paling dikenal dan banyak digunakan. Langkah yang digunakan dalam melakukan model the Big 6 yaitu sesuai dengan pendapat Yudistira (2017) yang mengemukakan bahwa mendefinisikan tugas, strategi pencarian informasi, lokasi dan akses, penggunaan informasi, sintesis, evaluasi.

1. Mendefinisikan tugas (Task Definition)

Mendefinisikan tugas (task definition) artinya kegiatan merumuskan dan menetapkan topik sebelum memulai penelitian/pembuatan makalah/tugas Hasil penelitian terhadap mahasiswa PGSD Kebumen FKIP UNS angkatan 2017 menunjukkan bahwa: mahasiswa PGSD Kebumen FKIP UNS angkatan 2017 
melakukan interaksi dengan dosen, teman, dan pustakawan untuk meminta saran dalam mengerjakan tugas. Namun, sebagian besar mahasiswa PGSD Kebumen FKIP UNS 2018 lebih sering bertanya kepada teman.

Keterangan_grafik:

1. Bertanya kepada
dosen

Grafik di samping menunjukkan bagaimana mahasiswa berdiskusi dengan dosen dalam menentukan topik untuk mengerjakan tugas. Dari tabel disamping terlihat bahwa 3\% mahasiswa (1 mahasiswa) mahasiswa menjawab sangat sering, sebanyak $36 \%$ mahasiswa (13 mahasiswa) menjawab sering, sebanyak 58\% mahasiswa ( 21 mahasiswa) menjawab jarang, dan sebanyak 3\% mahasiswa (1 mahasiswa) menjawab tidak pernah. Maka dapat disimpulkan bahwa mahasiswa PGSD Kebumen FKIP UNS angkatan 2017 kurang dalam hal melakukan tukar pendapat dengan dosen untuk mengerjakan tugas.

Keterangan_grafik:

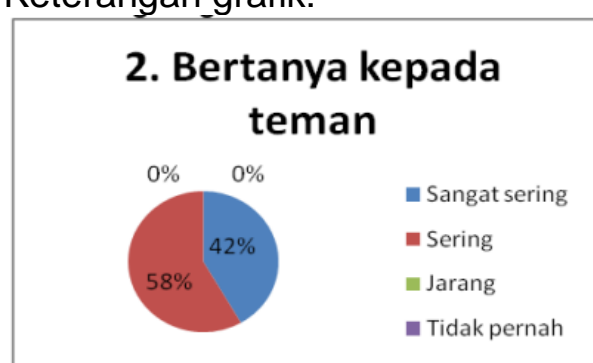

Grafik di samping menunjukkan bagaimana mahasiswa berdiskusi dengan teman dalam menentukan topik untuk mengerjakan tugas. Dari tabel disamping terlihat bahwa $42 \%$ mahasiswa (15 mahasiswa) mahasiswa menjawab sangat sering, sebanyak $58 \%$ mahasiswa (21 mahasiswa) menjawab sering, sebanyak $0 \%$ mahasiswa $(0$ mahasiswa) menjawab jarang, dan sebanyak 0\% mahasiswa (0 mahasiswa) menjawab tidak pernah. Maka dapat disimpulkan bahwa mahasiswa PGSD Kebumen FKIP UNS angkatan 2017 baik dalam hal melakukan tukar pendapat dengan teman untuk mengerjakan tugas.

Keterangan grafik:

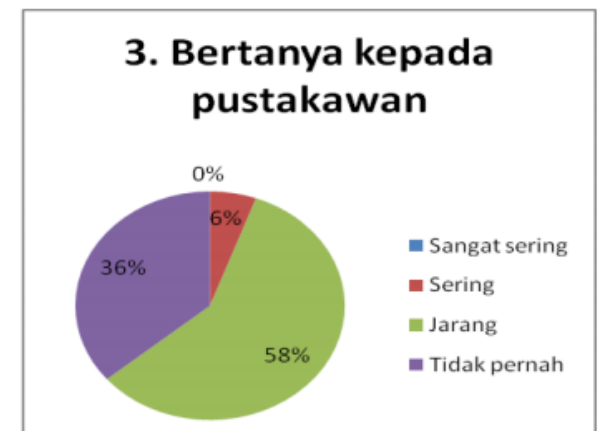

Grafik di samping menunjukkan bagaimana mahasiswa berdiskusi dengan pustakawan dalam menentukan topik untuk mengerjakan tugas. Dari tabel disamping terlihat bahwa $0 \%$ mahasiswa (0 mahasiswa) mahasiswa menjawab sangat sering, sebanyak $6 \%$ mahasiswa (2 mahasiswa) menjawab sering, sebanyak 58\% mahasiswa (21 mahasiswa) menjawab jarang, dan sebanyak 36\% mahasiswa (13 mahasiswa) menjawab tidak pernah. Maka dapat disimpulkan bahwa mahasiswa PGSD Kebumen FKIP UNS angkatan 2017 kurangberinteraksi dengan pustakawan dalam hal mengerjakan tugas.

2. Strategi Pencarian Informasi (Information Seeking Strategies)

strategi pencarian informasi (information searching strategies) artinya kemampuan dalam menentukan sumber-sumber informasi dan mengevaluasinya. Hasil penelitian terhadap mahasiswa PGSD Kebumen FKIP UNS angkatan 2017 menunjukkan bahwa: mahasiswa PGSD Kebumen FKIP UNS angkatan 2017 baik dalam hal menelusuri informasi, hal itu terlihat dari tingginya penggunaan sumber 
primer dan sekunder.

Keterangan grafik:

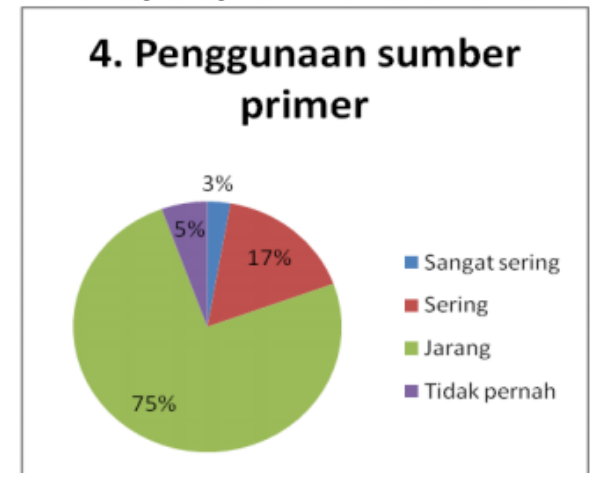

Grafik di samping menunjukkan bagaimana mahasiswa menggunakan sumber primer untuk mengerjakan tugas. Dari tabel disamping terlihat bahwa 3\% mahasiswa (1 mahasiswa) mahasiswa menjawab sangat sering, sebanyak $17 \%$ mahasiswa (6 mahasiswa) menjawab sering, sebanyak 75\% mahasiswa (27 mahasiswa) menjawab jarang, dan sebanyak 5\% mahasiswa (2 mahasiswa) menjawab tidak pernah. Maka dapat disimpulkan bahwa mahasiswa PGSD

Kebumen FKIP UNS angkatan 2017 kurang baik dalam pemanfaatan penggunaan sumber primer.

Keterangan grafik:

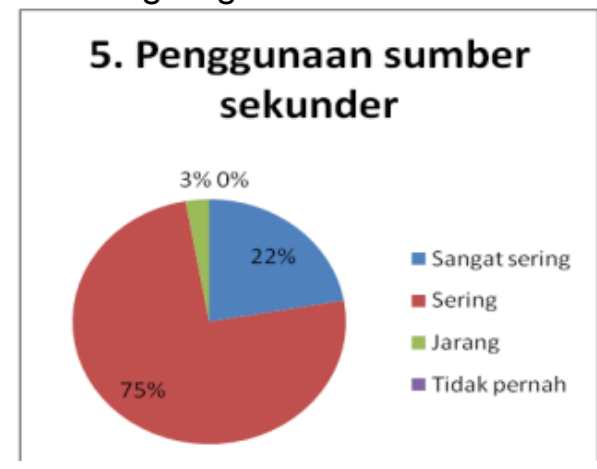

Grafik di samping menunjukkan bagaimana mahasiswa menggunakan sumber sekunder untuk mengerjakan tugas. Dari tabel disamping terlihat bahwa $22 \%$ mahasiswa (8 mahasiswa) mahasiswa menjawab sangat sering, sebanyak $75 \%$ mahasiswa (27 mahasiswa) menjawab sering, sebanyak $3 \%$ mahasiswa (1 mahasiswa) menjawab jarang, dan sebanyak $0 \%$ mahasiswa (0 mahasiswa) menjawab tidak pernah. Maka dapat disimpulkan bahwa mahasiswa PGSD Kebumen FKIP UNS angkatan 2017 sangat baik dalam pemanfaatan sumber sekunder.

\section{Lokasi dan Akses (Location and Access)}

Tahap lokasi dan akses artinya mencoba menggali sumber yang tersedia. Hasil penelitian terhadap mahasiswa PGSD Kebumen FKIP UNS angkatan 2017 menunjukkan bahwa: mahasiswa PGSD Kebumen FKIP UNS angkatan 2017 baik dalam pencarian informasi dengan melakukan kunjungan ke perpustakaan, namun mereka lebih sering menggunakan search engine karena dianggap lebih praktis dan mudah.

Keterangan grafik:

\section{Kunjungan ke perpustakaan}

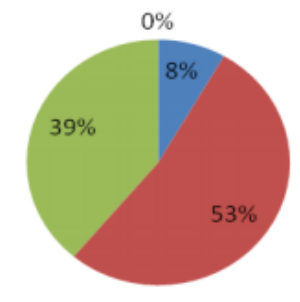

- Sangat sering

= Sering

= Jarang

- Tidak pernah
Grafik di samping menunjukkan frekuensi penggunaan perpustakaan sebagai tempat mencari informasi untuk mengerjakan tugas. Dari tabel disamping terlihat bahwa $8 \%$ mahasiswa (3 mahasiswa) mahasiswa menjawab sangat sering, sebanyak $53 \%$ mahasiswa (19 mahasiswa) menjawab sering, sebanyak $39 \%$ mahasiswa (14 mahasiswa) menjawab jarang, dan sebanyak 0\% mahasiswa (0 mahasiswa) menjawab 
tidak pernah. Maka dapat disimpulkan bahwa mahasiswa PGSD Kebumen FKIP UNS angkatan 2017 sangat baik dalam mencari informasi di perpustakaan.

Keterangan grafik:

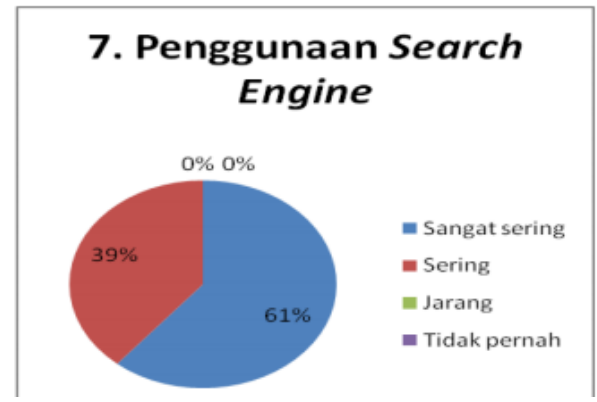

Grafik di samping menunjukkan bagaimana mahasiswa menggunakan search engine dalam mencari informasi untuk mengerjakan tugas. Dari tabel disamping terlihat bahwa $61 \%$ mahasiswa (22 mahasiswa) mahasiswa menjawab sangat sering, sebanyak $39 \%$ mahasiswa (14 mahasiswa) menjawab sering, sebanyak $0 \%$ mahasiswa $(0$ mahasiswa) menjawab jarang, dan sebanyak $0 \%$ mahasiswa (0 mahasiswa) menjawab tidak pernah. Maka dapat disimpulkan bahwa mahasiswa PGSD Kebumen FKIP UNS angkatan 2017 sangat baik dalam mencari informasi menggunakan search engine.

4. Penggunaan Informasi (Use of Information)

Penggunaan informasi (use of information) artinya tahap ini membutuhkan kesediaan dalam melihat, membaca dan mendengar untuk menemukan faktafakta yang dibutuhkan dalam menjawab permasalahan Hasil penelitian terhadap mahasiswa PGSD Kebumen FKIP UNS angkatan 2017 menunjukkan bahwa: mahasiswa PGSD Kebumen FKIP UNS angkatan 2017 lebih memilih menggunakan dokumen digital dibandingkan menggunakan dokumen tercetak.

Keterangan grafik:

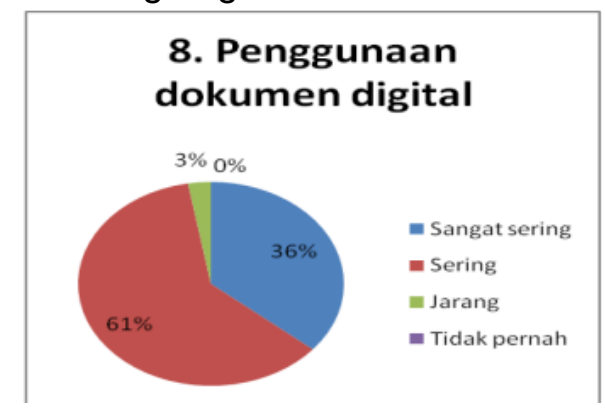

Grafik di samping menunjukkan frekuensi penggunaan dokumen dalam bentuk digital untuk mengerjakan tugas. Dari tabel disamping terlihat bahwa $36 \%$ mahasiswa (13 mahasiswa) mahasiswa menjawab sangat sering, sebanyak $61 \%$ mahasiswa ( 22 mahasiswa) menjawab sering, sebanyak $3 \%$ mahasiswa (1 mahasiswa) menjawab jarang, dan sebanyak $0 \%$ mahasiswa (0 mahasiswa) menjawab tidak pernah. Maka dapat disimpulkan bahwa mahasiswa PGSD Kebumen FKIP UNS angkatan 2017 baik dalam menggunakan dokumen dalam bentuk digital.

Keterangan grafik:

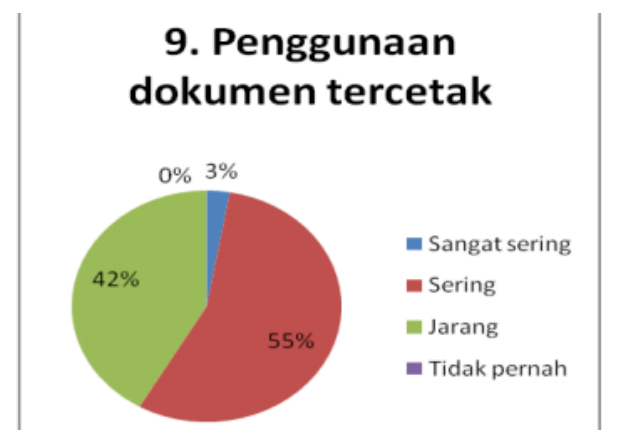

Grafik di samping menunjukkan bagaimana mahasiswa menggunakan dokumen tercetak untuk mengerjakan tugas. Dari tabel disamping terlihat bahwa $3 \%$ mahasiswa (1 mahasiswa) mahasiswa menjawab sangat sering, sebanyak $55 \%$ mahasiswa (20 mahasiswa) menjawab sering, sebanyak 42\% mahasiswa (15 mahasiswa) menjawab jarang, dan sebanyak $0 \%$ mahasiswa $(0$ mahasiswa) menjawab tidak pernah. Maka dapat disimpulkan bahwa mahasiswa PGSD Kebumen FKIP UNS angkatan 2017 baik dalam menggunakan dokumen digital untuk mengerjakan tugas. 


\section{Sintesis (Synthesis)}

Sintesis (synthesis) artinya tahap ini menyatukan informasi-informasi yang didapatkan sehingga dapat menjawab permasalahan yang dicari Hasil penelitian terhadap mahasiswa PGSD Kebumen FKIP UNS angkatan 2017 menunjukkan bahwa: mahasiswa PGSD Kebumen FKIP UNS angkatan 2017 sangat baik dalam menggunakan informasi dengan mencantumkan kutipan dan menuliskan daftar pustakan yang sesuai dengan ketentuan akademik.

Keterangan grafik:

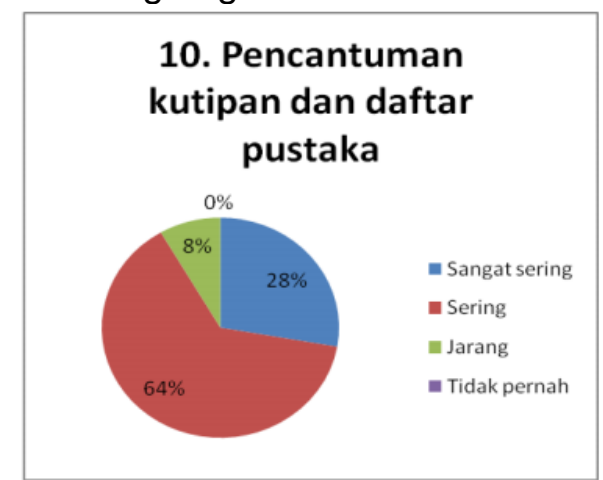

Grafik di samping menunjukkan bagaimana frekuensi dalam mencantumkan kutipan dan menuliskan daftar pustaka dalam menggunakan informasi untuk mengerjakan tugas. Dari tabel disamping terlihat bahwa 28\% mahasiswa (10 mahasiswa) mahasiswa menjawab sangat sering, sebanyak $64 \%$ mahasiswa (23 mahasiswa) menjawab sering, sebanyak $8 \%$ mahasiswa (3 mahasiswa) menjawab jarang, dan sebanyak $0 \%$ mahasiswa (0 mahasiswa) menjawab tidak pernah. Maka dapat disimpulkan bahwa mahasiswa PGSD Kebumen FKIP UNS angkatan 2017 baik dalam mencantumkan kutipan dan disertai daftar pustaka.

\section{Evaluasi (Evaluation)}

Evaluasi (evaluation) artinya tahap ini mengevaluasi apakah tugas terselesaikan dan apakah masalah terselesaikan. Hasil penelitian terhadap mahasiswa PGSD Kebumen FKIP UNS angkatan 2017 menunjukkan bahwa: mahasiswa PGSD Kebumen FKIP UNS angkatan 2017 sudah baik dalam melakukan evaluasi terhadap suatu hasil kegiatan.

Keterangan grafik:

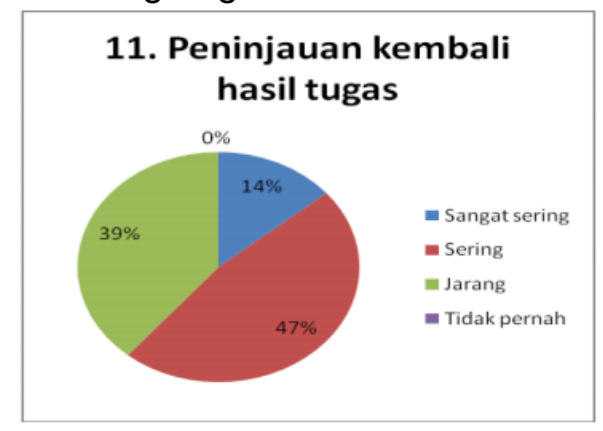

Grafik di samping menunjukkan bagaimana frekuensi mahasiswa melakukan terhadap hasil tugas. Dari tabel disamping terlihat bahwa 14\% mahasiswa (5 mahasiswa) mahasiswa menjawab sangat sering, sebanyak $47 \%$ mahasiswa (17 mahasiswa) menjawab sering, sebanyak 39\% mahasiswa (14 mahasiswa) menjawab jarang, dan sebanyak $0 \%$ mahasiswa (0 mahasiswa) menjawab tidak pernah. Maka dapat disimpulkan bahwa mahasiswa PGSD Kebumen FKIP UNS angkatan 2017 baik dalam melakukan evaluasi terhadap hasil tugas dengan mengecek kembali hasil tugas sesuai dengan kaidah ilmiah. 


\section{SIMPULAN}

Berdasarkan uraian pada pembahasan, dapat disimpulkan bahwa:

1. Mahasiswa PGSD Kebumen FKIP UNS angkatan 2017 melakukan interaksi dengan dosen, teman, dan pustakawan untuk meminta saran dalam mengerjakan tugas. Namun, sebagian besar mahasiswa PGSD Kebumen FKIP UNS 2018 lebih sering bertanya kepada teman.

2. Mahasiswa PGSD Kebumen FKIP UNS angkatan 2017 baik dalam hal menelusuri informasi, hal itu terlihat dari tingginya penggunaan sumber primer dan sekunder.

3. Mahasiswa PGSD Kebumen FKIP UNS angkatan 2017 baik dalam pencarian informasi dengan melakukan kunjungan ke perpustakaan, namun mereka lebih sering menggunakan search engine karena dianggap lebih praktis dan mudah.

4. Mahasiswa PGSD Kebumen FKIP UNS angkatan 2017 lebih memilih menggunakan dokumen digital dibandingkan menggunakan dokumen tercetak.

5. Mahasiswa PGSD Kebumen FKIP UNS angkatan 2017 sangat baik dalam menggunakan informasi dengan mencantumkan kutipan dan menuliskan daftar pustakan yang sesuai dengan ketentuan akademik.

6. Mahasiswa PGSD Kebumen FKIP UNS angkatan 2017 sudah baik dalam melakukan evaluasi terhadap suatu hasil kegiatan.

Pada penelitian ini dibuktikan bahwa model literasi informasi big six sudah diterapkan oleh mahasiswa PGSD UNS angkatan 2017 hal ini terlihat dari terpenuhinya setiap indikator dalam keenam langkah big six.

Berdasarkan simpulan dan implikasi yang telah disebutkan, peneliti memberikan rekomendasi kepada mahasiswa dianjurkan untuk mempelajari lebih dalam pada tahapan penggunaan informasi ,yaitu dengan cara menganalisis/memeriksa setiap informasi yang diperoleh sebelum informasi tersebut digunakan karena dari informasi yang didapatkan belum tentu sesuai dengan kebutuhan untuk memecahkan masalah yang dihadapi.

\section{DAFTAR PUSTAKA}

Badan Standardisasi Nasional. (2000). Perpustakaan Perguruan Tinggi.Jakarta: BSNSNI-2009.

Nurtiar, H. (2012). Tingkat Kemampuan Litrasi Informasi Mahasiswa Skripsi: Studi Perbandingan FIK dan FKM UI. Universitas Indonesia: Depok

Nurohman, A. (2014). Signifikansi Literasi Informasi(Information Literacy)Dalam Dunia Pendidikan di Era Global. Jurnal Kependidikan. 3 (4). 4

Paramida, K. \& Rachman, Y. B. (2013). Kemampuan Literasi Informasi Mahasiswa Fakultas IImu Pengetahuan Budaya Universitas Indonsia Angkatan 20012. Universitas Indonesia: Depok.

Pendit, P. L. (2008). Perpustakaan Digital dari A sampai Z. Jakarta: Cita Karya Karsa Mandiri.

Sulistyo, B. (2006). Pengantar Imu Perpustakaan dan Informasi. Jakarta: Gramedia.

The Society of College, National and UniversityLibraries. (2011). The SCONUL Seven Pillarsof Information Literacy: Core Model ForHigher Education. UK: SCONUL WorkingGroup on Information Literacy.

Yudistira. (2017). Literasi Informasi Pustakawan Di Perpustakaan Fakultas Teknik Ugm Menggunakan PengembanganModel The Big6. Berkala IImu Perpustakaan dan Informasi, 13 (1), 3. 